\title{
Civility In The University Classroom: An Opportunity For Faculty To Set Expectations
}

Chris Ward, University of Findlay, USA

Dan Yates, University of Findlay, USA

\begin{abstract}
This research examines the types of uncivil behaviors frequently encountered in university classrooms. These behaviors range from walking in late to class, texting in class, and/or unprofessional emails. These behaviors can often undermine a professor's teaching. Setting reasonable and consistent expectations is a combination of university policy, faculty enforcement, and possibly even input from students. While it is understood that we live in a digitally connected world, there is an opportunity for professors to exhibit and reinforce professional behavior that students will be expected to demonstrate in the workplace.
\end{abstract}

Keywords: Civility; Professionalism; Undergraduate Students; Classroom Behavior

\section{INTRODUCTION}

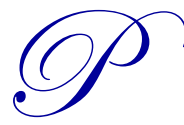

M. Forni, author of several books on civility, commented in 2008, "For quite some time, we have observed that the disengaged, disrespectful, and unruly student behavior that used to be confined to secondary schools has reached higher education" (p. 15). Students' beliefs or attitudes that certain behaviors, including walking into class late, texting during class, talking while the professor is talking, etc., are acceptable and faculty observe these behaviors on a daily basis.

The term civility is used in a broad sense to include respect for one another, tolerance of ideas and persons, good manners, and even the Golden Rule. Connelly (2009) claimed that civility is "a virtue in the sense of a learned capability, habit, disposition, or character trait based on the sincere belief in the value of living as part of a diverse community and the conviction that the goal of living successfully in each community calls us to serve the common good, not just function out of self-interest" (p. 52). We accept this definition of civility moving forward. Connelly (2009) also envisioned five virtues of civility that enable an individual to navigate this sometimes changing landscape. First, he stated is to "recognize the differences in various communities"; second is to "identify the accepted social norms/values that generally govern good relations for each community in which one is involved"; third, "be flexible and adaptable enough to live by the norms of a given community in the spirit of getting along well with other members in the community"; fourth was to "know when to switch/shift/modify behavior and be guided by other norms, as necessary, to fit into another community"; and fifth, "be tolerant of defects or imperfections in norms in order to maintain mutual trust in a community" (pp. 52-53). These broad, but succinct, values can apply to any company, community, or country and are something students must be aware of as they go about their daily interactions and certainly when they enter the workforce.

The focus of this paper is to develop an understanding of the current issue of civility in higher education, identify potential solutions to incivility in the classroom, and how these multiple definitions fit into $21^{\text {st }}$ century learning outcomes. 


\section{CURRENT ISSUES OF CIVILITY IN THE CLASSROOM}

The literature is littered with various examples of incivility. While they may be categorized differently, common examples include bullying/sarcasm/arguing (Boice, 1996; Morrissette, 2001; Feldmann, 2001; Connelly, 2009; Alkandari, 2011; Seganish \& Holter, 2013), unwilling to participate in the learning process (Morrissette, 2001), students talking while the professor is lecturing (Boice, 1996; Connelly, 2009; Alexander, Mundrake, \& Brown, 2009; Nordstrom, Bartels, \& Bucy, 2009; Alkandari, 2011), students coming into class late or leaving early (Boice, 1996; Feldmann, 2001; DiClementi \& Handelsman, 2005; Connelly, 2009; Alexander, Mundrake, \& Brown, 2009; Alkandari, 2011; Seganish \& Holter, 2013), cell phone usage such as taking a call or texting (Feldmann, 2001; DiClementi \& Handelsman, 2005; Connelly, 2009; Alexander, Mundrake, \& Brown, 2009; Nordstrom, Bartels, \& Bucy, 2009; Alkandari, 2011; Seganish \& Holter, 2013), doing homework or reading for another class (Feldmann, 2001; Alexander, Mundrake, \& Brown, 2009; Alkandari, 2011; Seganish \& Holter, 2013), reading a newspaper (Feldmann, 2001; Nordstrom, Bartels, \& Bucy, 2009), expecting the professor to take responsibility of the student in the class - for example, print their assignment or bring a posted handout to class (Seganish \& Holter, 2013), browsing or using the web (Connelly, 2009; Alexander, Mundrake, \& Brown, 2009), sleeping in class (Connelly, 2009), and inappropriate emails to the professor (Connelly, 2009).

Numerous studies have been done and articles written as far back as Boyce (1996) on the subject of (in) civility, and, as discussed in the paragraphs above, the term is often used in a very broad sense. Alexander, Mundrake, and Brown (2009) observed classroom behavior and divided it into three areas: personal, technical, and collaborative. The personal behavior included coming to class late, talking while the instructor was talking, using profanity, reading non-class materials, and falling asleep. Technical behavior encompassed using or answering a cell phone, browsing/using the web, using headphones/iPods, playing games on the computer, and using a computer during instruction. The collaborative area included handing in someone else's work as his/her own, working as a group on an individual assignment, receiving help on a test from another student, giving information about a test to another student, and copying a file from a desktop or hard drive instead of doing their own work. Their study observed differences between pre-business college freshman and high school students, differences between prebusiness freshman and high school males and females, as well as the perception of acceptable behavior in these groups. Their results for the pre-business freshman found "For all items in three categories (personal, technical, and collaborative), the majority of the respondents 'strongly agreed' or 'agreed' that the behavior was unacceptable" (pp. 110-111). Of particular interest was that female pre-business freshman had five behaviors significantly more unacceptable when compared to the male pre-business freshman. These classroom behaviors included using profanity, sleeping, using headphones/iPods, handing in someone else's work as his/her own, and copying a file from the desktop or hard drive instead of doing the work on his/her own.

Alkandari (2011) conducted research on Kuwait University students' perception of the level of incivility in the classroom. Students' saw other students displaying unacceptable behavior, such as asking to be excused from a lecture, arriving late to class, students talking to one another while the professor was giving a lecture, being absent from class, and using a mobile phone to call or read messages during class. This author also suggested that females were engaging in more incivility than males but found no differences in incivility between the social sciences colleges and the scientific colleges. It is important to note that this author's finding regarding male and female incivilities were inconsistent with Alexander et al. (2009) noted earlier.

\section{POTENTIAL SOLUTIONS}

Developing potential solutions is a multi-faceted approach. It involves the institution directly with honor codes, rules regarding eating in specific classrooms, or talking on the cell phone being prohibited in libraries and computer labs. "Colleges have acceptable use policies, but students are often less aware of those policies and may believe they have more freedom to choose their classroom behaviors" (Alexander et al., 2009, p. 113). Instructors may add class specific policies as well. These codes of conduct/behavior are initiated by the instructor in the course syllabi and generally related to attendance, late assignments or other issues in an effort to clarify expectations and a sense of distributive fairness. Several studies have been done on the concept of the fairness of these policies as well as the possibility of considering student input during the development of course policies. DiClementi \& Handelsman (2005) suggest that student-generated course rules might be more effective. Their study divided the 
class into small groups with each group addressing one the following rules: eating in class, sleeping in class, coming to class late, and the use of cellphones/pagers. Students observed fewer violations of rules when they were able to develop their own rules. The authors attributed this to the students' sense of control that may have enhanced their investment in the class. In addition, an interesting observation was that the students had a better attitude toward the professor. While the authors note that there could be a bias on the part of the instructor, adopting this process certainly did no harm and could be useful. The study by Dulplaga \& Astani (2010) took a slightly different approach as they asked students about the 'fairness' of classroom policies, including attendance, late assignments and make-up exams, homework, and cheating. The most interesting, almost contradictory, results were $74 \%$ of students wanted a non-mandatory attendance policy; however, “...most students did not perceive a mandatory attendance policy as the fairest treatment; it appears that students prefer that attendance be taken and good attendance rewarded in some fashion" (p. 19). This locus of control appears to be a common thread of students and we recommend that faculty members review their course policies for fairness as well as how clear they are to students.

Institutions can play a large role by crafting across-the-board policies so that students know what to expect. Alexander et al. (2009) noted, "Establishing and enforcing rules in college classes about use of electronics may be needed" (p. 113). Alkandari (2011) agreed that higher education institutions should submit codes of conduct to manage student behavior in the classroom, but he also recognized it was still up to the faculty member to deal with student misconduct. An approach by the university could be to use freshman orientation to explain policies regarding their code of conduct and discipline policies. The author suggested that the university "...submit a policy that includes more details in explaining the valuable behavior expected from the students in the classroom" (p. 263). This would give a faculty member more support if students complain to their department chair or on course evaluations. In addition to a code of conduct policy, Alkandari (2011) also suggested limiting the number of students in the class to no more than 35, indicating those classes with 25 students or less showed little or no student misconduct. Seganish \& Holter (2013) added, "Civility problems can be exacerbated in 'large classroom environments' because of student anonymity and the lack of direct personal contact with the students" (p. 62). The issue of class size and its potential impact on civility would be a good point of discussion for the institution. A code of conduct, Morrissette (2001) noted, if not enforced by all faculty, is problematic. Faculty who do enforce the code of conduct often feel stressed, may hesitate to discuss it for fear of being criticized for their lack of classroom management skills, and could possibly get poor student evaluations impacting their ability to get tenure or promotion. This is supported by Alkandari's (2011) research on the students' perceptions of the faculty members' role in maintaining a civil classroom. Students reported that $82.8 \%$ of faculty informed them of the behavior they expected in class, $72.1 \%$ of faculty reprimanded a student for misbehavior, and $72.3 \%$ imposed a penalty of some sort for student misbehavior. Setting the tone appears to be critical to instill positive behaviors and faculty are not without their own personal responsibilities. In addition to what the faculty member expects from students, Forni (2008) provided five statements regarding what students should expect from the faculty member. These included being punctual for class, giving everyone a fair share of attention, preparing the students for a test, grading the quality - not the effort or time spent on their work, and helping all students to perform their best. He added, “... never cease to be clear-headed, temperate, considerate, and compassionate. Never argue or raise your voice" (p. 22). In the classroom or other forms of communication, faculty actions, whether it is lack of preparation, discounting or making fun of an opinion by a student, or not returning emails, etc. can often set the civility tone in their classes.

Some of these solutions may require a university code of conduct, possibly even developed in collaboration with students. It may also require the institution to provide training sessions for faculty on how to address incivility if it occurs in the classroom. Connelly (2009) even suggests, "The faculty handbook also may outline instructional duties or professional code of ethics" (p. 57).

\section{$21^{\text {st }}$ CENTURY LEARNING OUTCOMES}

Students generally understand how to behave in specific setting, such as church or family gatherings. However, the move from high school to college, and the expectations, can be quite different. The high school student may have been required, for example, to attend class or leave their cell phone in a locker and were faced with specific consequences if they violated these rules. The college student may feel more independent and need to develop specific professional dispositions, even when they are not obvious. Duplaga \& Astani (2010) reasoned 
"...that most college instructors attempt to prepare their students for the conditions they will face in the "real world" and, as such, may select policies that encourage certain types of conduct. For example, "conscientious class attendance (attendance policy) and on-time class assignments (late assignment policy) are important job-related behaviors that some student may not fully appreciate while they are going to school” (p. 10).

If we expect students to demonstrate civility when they graduate, then a clear definition of civility should be crafted and a plan to understand, apply and demonstrate civil behavior should be embedded throughout the curriculum. As a reminder, we accepted that civility is "a virtue in the sense of a learned capability, habit, disposition, or character trait based on the sincere belief in the value of living as part of a diverse community and the conviction that the goal of living successfully in each community calls us to serve the common good, not just function out of self-interest" (Connelly, 2009, p. 52). If we accept this definition, then this plan should start in a first-year experience class. The objective at this stage, Forni (2009) noted, is twofold. First is to learn what acceptable behavior is, "...including the often unspoken, but still expected, manner of acting and speaking in order to know what is takes to be academically successful in the student role," and second is "to help students begin to understand that there is a cluster of related concepts that identify some basic set of norms and values that go beyond any one community and are transportable from one community to another" (p. 55). These outcomes can then be reinforced in multiple classes and culminating in each program of study.

\section{CONCLUSION AND NEXT STEPS}

As professors, we certainly understand the 24-7 global environment and that current students have grown up being connected all the time; there does not seem to be an expectation of when and where these devices are appropriate. In addition, students need to be aware that various seemingly innocent behaviors, such as walking into class late or being unprepared, may reflect poorly on them in a professional setting. We cannot, however, expect these students to know how to behave in a professional setting if we don't take some of the responsibility to expect and demonstrate civil behavior in the classroom.

The next steps are two-fold. The plan is to develop a survey and distribute it to a variety of students to determine if specific certain behaviors (for example, being late for class) are more acceptable based on major, gender or rank. In addition, a proposal will be developed to add the book Choosing Civility by P. M. Forni to the required reading list for incoming freshman.

\section{AUTHOR INFORMATION}

Dr. Chris Ward is an Associate Professor of Business at the University of Findlay. She is currently the Chair of Business Administration programs and serves on the General Education, Faculty Development, and Faculty Affairs committees and as an accreditation co-chair of HLC Criterion 4. Professor Ward holds the following degrees: University of Sarasota, EdD, Organizational Leadership; MBA, and BS in Business Administration from the University of Findlay. She is also a Six Sigma Black Belt, a 2008 and 2010 Ohio Partnership for Excellence Examiner, and NxLevel Instructor. Her areas of research include student engagement and leadership, civility, and personal branding. E-mail: cward@ findlay.edu (Corresponding author)

Dan Yates is an Associate Professor of Business at the University of Findlay. His teaching interests include entrepreneurship, leadership, organization development, and business strategy. Yates holds a PhD degree in Management from Northcentral University. He also has a MBA from University of Dayton, a Master of Organization Development degree from Bowling Green State University, and a BS in Accounting from Tiffin University. He completed the NxLevel Certification Course for Instructor Certification for teaching business plans at the Innovation Center (Ohio University). He has 30 years industrial and governmental experience. E-mail: yates@findlay.edu

\section{REFERENCES}

1. Alexander, M. W., \& Mundrake, G. A. (2009, Spring/Summer). Pre business college freshman perception of classroom behavior: An analysis among and between genders. The Delta Pi Epsilon Journal, LI(2), 99116. 
2. Alkandari, N. (2011, June). The level of student incivility: The need of a policy to regulate college student civility. College Student Journal, 45(2), 257-269.

3. Boice, B. (1996). Classroom incivlities. Research in Higher Education, 37(4), 453-486.

4. Connelly, R. J. (2009). Introducing a culture of civility in first-year college classes. The Journal of General Education, 58(1), 47-64.

5. DiClementi, J., \& Handelsman, M. M. (2005). Empowering students: Class-generated course rules. Teaching of Psychology, 32(1), 18-21.

6. Duplaga, E., \& Astani, M. (2010, January). An exploratory study of student perceptions of which classroom polocies are fairest. Decision Sciences Journal of Innovative Education, 8(1), 9-33.

7. Feldmann, L. J. (2001). Classroom civility is another of our instructor responsibilities. College Teaching, 49(4), 137-140.

8. Forni, P. (2008, Fall). The civil classroom in the age of the net. Thought \& Action, 15-22.

9. Morrissette, P. (2001). Reducing incivility in the university/college classroom. International Electronic Journal of Leadership and Learning, 5(4), 1-13.

10. Nordstrom, C., Bartels, L., \& \& Bucy, J. (2009, March). Predicting and curbing classroom incivility in higher education. College Student Journal, 43(1), 74-85.

11. Seganish, W. M. (2013). A code of civility for the university setting: The architecture for implementation. Journal of Legal, Ethical and Regulatory Issues, 16(1), 57-71.

12. Von Bergen, C., Bressler, M., \& Collier, G. (2012). Creating a culture and climate of civility in a sea of intolerance. Journal of Organizational Culture, Communication and Climate, 16(2), 95-114. 


\section{NOTES}

